\title{
The Reform and Harmonization of Commercial Laws in the East African Community ${ }^{*}$
}

\author{
Agasha Mugasha**
}

\begin{abstract}
The partner states in the East African Community (EAC) have modernized their commercial laws to claim their post-colonial identity and facilitate development. While law reform and the harmonization of laws are both methods of shaping laws, the national law reform programmes in the EAC mainly aim to ensure that the laws reflect the domestic socioeconomic circumstances, in contrast to the harmonization of national commercial laws, which focuses on the attainment of economic development. This article observes that the reformed and harmonized commercial laws in the EAC are mainly legal transplants of the principles of transnational commercial law that have been adapted to meet domestic needs and aspirations.
\end{abstract}

Keywords: law reform, harmonization of laws, commercial laws, legal transplants, East African Community.

\section{A Introduction}

This article enquires if the recent major law reform exercise on commercial law in the East African Community (also referred to as EAC), together with the exercise on the harmonization of national commercial laws, succeeded in their set objectives of making laws that reflect the contemporary socioeconomic circumstances and facilitate development. Such a positive review would contrast with the muchvilified received colonial and immediate post-independence commercial laws, which were widely perceived as out of touch with the local population and focused

* Acknowledgments: Karen Hulme, Sabine Michalowski, former colleagues at the Uganda Law Reform Commission and the East African Community Sub-Committee on the Harmonisation of Laws; participants at International Academy of Commercial and Consumer Law in 2014; and participants at the Law Reform Project at the Institute of Advanced Studies, University of London in 2016. All errors are mine.

** Professor of Law, University of Essex; and former Chairperson, Uganda Law Reform Commission 2011-2015. 
on a detrimental export-oriented economy. ${ }^{1}$ This article focuses on commercial law reform during the period 1995-2015. Law reform in the present context means making recommendations for new laws or modifying the substance of existing laws by a designated law reform agency; successful reform ends in the passage of the recommended laws by the national legislature. ${ }^{2}$ Law reform is, thus, a distinct step in the law-making process within the legal system and the wider functioning of government systems. The second limb of the article, the harmonization of national commercial laws, also results in changes to the substance of the laws or the addition of new laws on the statute book, much like national law reform, even though the two processes are technically different. Harmonization, broadly, is the process of bringing laws on the same subject among countries or regions closer together. ${ }^{3}$ While both commercial law reform and the harmonization of national commercial laws have, broadly, the same objective of shaping laws, law reform emphasizes compatibility of the laws with contemporary social and economic circumstances, as will be later explained, and will be evaluated primarily on that basis. On the other hand, the harmonization of national laws is intended to facilitate economic growth and development generally, and will be evaluated on that basis. ${ }^{4}$ The article observes quite early that many of the reformed laws were transplanted from the US or UK, and that the harmonization of national laws followed the precedents in Europe, in similar fashion to the reception of colonial laws. It then proceeds to examine whether that transplantation process still fulfils the mandate of the law reform commissions to recommend laws in accordance with the local contemporary circumstances and whether the harmonization process is geared towards development.

This article contends that the development and modernization of commercial law in the EAC through national law reform programmes and the EAC harmonization of national laws has largely adopted the principles of transnational commercial law, similar to, but not identical with, the received law in the colonies which, on reflection, was the transnational commercial law of the day. Transnational commercial law is a set of rules with universal application because they arise from a convergence of legal systems and draw from different sources including international and regional instruments, international trade usages and customs, conscious or unconscious judicial or legislative parallelism, contractually incorporated rules and trade terms promulgated by international organizations, standard

1 There was an ideological flavour to some of the criticism; see e.g. K. Nkrumah, Neo-Colonialism, The Last Stage of Imperialism, Thomas Nelson \& Sons, Ltd., London, 1965; D. Nabudere, The Political Economy of Imperialism: Its Theoretical and Polemical Treatment from Mercantilist to Multilateral Imperialism, Zed Press, London, 1977; and more recently, O. Chung, 'The Lopsided International Investment Law Regime and Its Effect on the Future of Investor-State Arbitration', Virginia Journal of International Law, Vol. 47, 2007, p. 954; and A. Anghie, 'Legal Aspects of the New International Economic Order', International Journal of Human Rights, Humanitarianism, and Development, Vol. 6, No. 1, 2015, p. 145.

2 M. Ng'ang'a, 'Law Reform: Best Practices and Way Forward', Uganda Living Law Journal, Vol. 8, 2015, p. 36.

3 See part D, below.

4 The Treaty for the Establishment of the East African Community (hereinafter 'EAC Treaty'), article 5(3) also mentions the secondary objective of strengthening social, cultural and other ties. 
form contracts, restatements of scholars, and general principles of international law. ${ }^{5}$ Unlike the received law, however, the processes of reforming and harmonizing commercial laws in the EAC had a substantial local input that endeavoured to adapt the new laws to the local contemporary circumstances as required by policymakers. Thus, even if the content of the new commercial laws is conceptually similar to the foreign laws in the same way as the received law was, the process of considering it in the context of law reform and the harmonization of laws ensured that the new law was not simply and uncritically transplanted, but rather the compatibility with contemporary circumstances was carefully considered. The article documents and analyses hitherto undocumented practices in the EAC partner states and notes that the states have made big advancements in shaping their own laws. While the distinctiveness of the results are less pronounced in commercial law, which is more driven by global standards, than areas of law driven by personal and cultural factors such as family law or traditional justice systems, ${ }^{6}$ the article makes an original contribution to the literature on the processes of law reform and the harmonization of national laws and the development of law generally.

The article is divided into four parts following this introduction. Part B presents pertinent background information on the EAC partner states; in particular it brings out their post-colonial similarity in the quest for a legal system that is sensitive to domestic needs. Part $C$ analyses the major commercial law reform exercise that lasted approximately 20 years. Since law reform is a national exercise, the article predominantly relies on Uganda for accuracy, but brief outlines and legislative results from the other partner states are also presented. This part illustrates that there was a deliberate and concerted effort to make laws that conform to the local contemporary circumstances, but nonetheless the new laws were transplants from overseas jurisdictions. The part observes that the transplantation was inevitable and beneficial. Part D analyses the harmonization of the national commercial laws in the EAC focusing on the use of the EAC directives in the capital markets. This part notes that the harmonization process is inspired by overseas models both in the process and substance of the commercial laws, but nonetheless, the process ends up with local participation and control. The final part is the conclusion, which again reflects on the partner states' requirement to make laws whose formulation, harmonization and content reflect the local circumstances. It notes that because the subject matter of the reform and harmonization exercises was commercial law, the result of the reform and harmonization exercises is the adoption of principles of transnational commercial law.

The article relies on library research and participant-observation, since the author was a participant in the law reform activities in Uganda and the harmonization of laws processes in the EAC. The dearth of legal literature to guide the EAC on the harmonization of laws, contrasted to the abundance of literature on

5 See R. Goode, H. Kronke \& E. McKendrick, Transnational Commercial Law, 2nd edn., Oxford University Press, Oxford, 2015, pp. 32-34.

6 To illustrate uniqueness of family law, Kenya in 2015 legislated for polygamy, and nearly all the EAC have legislated that moslem men can marry up to four wives. 
harmonization in the European Union led the author to reason by analogy to European law as necessary. This being a study on the making and improvement of legal rules, it defers to official documents on development theory and public policy as articulated by experts in those fields and does not critically debate them.

\section{B Context and Infrastructure for Law Reform}

The East African Community comprises of the sovereign neighbouring states of Kenya, Uganda, Tanzania, Rwanda, Burundi and South Sudan. ${ }^{7}$ All of them formerly colonized and now republics, the six Partner states aim, ultimately, to form a political federation, and have agreed on the interim steps of a customs union, common market, and monetary union. ${ }^{8}$ These economic and political arrangements are premised on the need for a sound legal system that enables the member states to achieve their main objectives of development and prosperity through regional and international trade and investment. A particularly important suite of laws that have been recently reformed at the national level and harmonized at the regional level as an avenue to prosperity are those that relate to business and finance, ${ }^{9}$ compendiously called commercial laws, which have attracted particular vigour because of the widely held perception that developed nations are wealthy through business and finance and that developing nations should follow the same proven path to prosperity. ${ }^{10}$

Despite the shared identity and stated common aspirations, the EAC partner states are diverse in the legal and economic infrastructure in a way that influences the practicality of law reform and the harmonization of national laws. Deriving from their different colonial history, their legal systems are different. Uganda, Kenya and Tanzania have a mixture of Common Law and customary law, while Rwanda and Burundi traditionally had Civil Law and customary law. With an urban population of only $22 \%$, this predominantly rural-based region boasts of the cultural diversity of over 250 different tribes among its 150 million people. Economically, the partner states are at slightly different stages of development and have previously pursued different models to development. Kenya, with an estimated per capita income of $\$ 1,800$, has always had a market economy, in contrast to Tanzania, which experimented with socialism for a few decades after independence; and in further contrast to Burundi and South Sudan, which recently experienced prolonged instability and have per capita incomes hovering around $\$ 600$. In broad outline, though, all the countries are on the lower end of the global economic spectrum. The main implication is that the usual problems

$7 \quad$ EAC Treaty, article 3.

8 Ibid., article 5.

9 A similar reform and harmonization project has taken place in 16 West African countries, the majority of whom are Franco-phone: see B. Martor et al., Business Law in Africa: OHADA and the Harmonisation Process, 2nd edn., GMB Publishing, London, 2007; J. Kodo, 'Harmonisation of Business Law: The Experience of Africa', in M. Andenas \& C.B. Andersen, Theory and Practice of Harmonisation, Edward Elgar, Cheltenham, UK, 2011, pp. 252-267.

10 A recent powerful statement is $\mathrm{H}$. de Soto, The Mystery of Capital: Why Capitalism Triumphs in the West and Fails Everywhere Else, Basic Books Publications, New York, NY, 2000. 
caused by financial constraints in any society are amplified in areas that are relevant to this research; such as efficiencies in bureaucracies and ownership of programmes. Generally, all the partner states are not very efficient in their government processes and they frequently rely on donor funding for programmes such as law reform and the harmonization of laws.

The large project on the reform of commercial laws in the East African community, running approximately from 1995 to 2015 in Uganda, ${ }^{11}$ and overlapping at the tail end of that period with the project on the harmonization of national commercial laws, presented the EAC partner states an immense opportunity to chart their own course away from the colonial, received laws that were on the statute books for more than a century to indigenous, home-grown laws. The colonial commercial law statute book, which continued to apply almost in its entirety after independence, was much vilified based on both sentiment and reality. To illustrate the latter, the requirement for law students to study statutes such as the Bills of Exchange Act, ${ }^{12}$ and distinguish between cheques, bills of exchange and promissory notes, when nearly all the population did not have bank accounts, illustrated the mismatch between the law and the population. The study of business associations was similarly castigated for its preoccupation with public companies in the Companies Acts ${ }^{13}$ when the large majority of local enterprises were un-incorporated and sole-owned. These and other examples ${ }^{14}$ inculcated an acute awareness of the desire to have indigenous laws that reflected the needs of the local population.

It was that sensitivity about redundant or discordant foreign laws on the statute book that made it imperative for the EAC countries to direct explicitly that their domestically enacted laws must comport with the local circumstances. For instance, the Uganda Law Reform Commission Act ${ }^{15}$ requires the Commission to spearhead the making of laws that take into account the prevailing socioeconomic circumstances. Section 10 of that Act specifies the functions of the commission as follows:

The commission shall study and keep under constant review the Acts and other laws comprising the laws of Uganda with a view to making recommendations for their systematic improvement, development, modernisation and reform with particular emphasis on -

11 The legislative result in the other EAC countries is presented later.

12 Laws of Uganda 2000 Revised edition, Cap 68.

13 The post-independence Companies Acts in East Africa were adaptations of the UK Companies Acts of 1929 and 1948: see A. Hussain, A Textbook of Company Law in Kenya, Heinemann, Nairobi, 1980, p. 1.

14 The negative perception of the law was better illustrated by classic cases outside commercial law and perhaps best illustrated by the court case of R. $v$ Amkeyo (1917) 7 EALR 14 taught in criminal, evidence and family law in the three common law countries, where the colonial judge Hamilton dismissed African marriages as mere wife purchase. 
- the elimination of anomalies in the law, the repeal of obsolete and unnecessary laws and the simplification and translation of the law;

- the reflection in the laws of Uganda of the customs, values and norms of society in Uganda as well as concepts consistent with the United Nations Charter for Human Rights and the Charter of Human and Peoples' Rights of the Organisation for African Unity;

- the development of new areas in the law by making the laws responsive to the changing needs of the society in Uganda; ...

Similarly, in Tanzania, it is a requirement that the reforms on policy, legal and institutional frameworks takes into account the contemporary social and economic developmental dimensions at regional and international levels. ${ }^{16}$ The mission statement of the Commission is explicit:

To reform and develop the laws of the United Republic of Tanzania in accordance with the values enshrined in the Constitution to meet the economic, social, cultural and political needs of the changing society. ${ }^{17}$

While those "values" and "norms" of society are not defined and there would be no unanimity about their exact content, the popular meaning imposes an overriding mission to enact laws that do not denigrate or contradict the social and cultural norms of society. The law reform research staff are required to investigate and accurately gauge those needs and values through continuous research and interaction government, the public and a wide variety of stakeholders described in part $C$, and the ultimate authority to decide on compliance in any draft legislation lies with Parliament. In contrast to the uncertain meaning of social and cultural needs or contemporary circumstances, the developmental or prosperity objective for the East African Community partner states is defined, widely, but the economic sense comes out clearly sitting above other aspects of development, as can be gleaned from the objectives of the EAC. ${ }^{18}$

As seen above, the mandate for reforming the national laws has been given to the national law reform commissions. While the law reform commissions do not have exclusive mandates, they have been equipped with the financial and human resources and are the preferred choice by government in reforming and developing the law. The law reform commissions also act by way of delegated authority and lead on the harmonization of national laws, which, under Article 126(2)(b) of the Treaty on the Establishment of the East African Community is formally a task of the Sectoral Council on Legal and Judicial Affairs (SCLJA).

16 See Law Reform Commission of Tanzania Act, 1980 section 4; and Kenya Law Reform Commission Act, 2013 section 6.

17 Available at: <www.lrct.go.tz> (last accessed 25 July 2017).

18 See also Protocol on the Establishment of the East African Community Common Market (hereinafter, EAC Common Market Protocol) article 4(2). 


\section{Conceptualization, Process and Results of Commercial Law Reform in the EAC}

\section{Conceptualization of the Law Reform Project}

The major commercial reform project in Uganda was multilateral agency driven and funded, consultant-led, and locally controlled. The project, which started in 1995, was designed by the World Bank, which also determined the methodology for the execution of the project. ${ }^{19}$ Forty-four commercial laws were identified for reform, of which 17 were prioritized, completed and are the focus of the present commentary.

The conceptualization of the law reform exercise was driven by globalization set in the context of geopolitical and economic imperatives. In that era of "universalism", 20 there was a unity of purpose between the advanced, Western nations and the developing countries even though their reasons were different. The Western countries were looking for new markets and opportunities for trade and investment; and initially, sections of the developing community saw globalization as favouring the metropolitan countries because the laws tended to require developing countries to open their markets. By the 1990s, however, globalization was also seen as benefitting developing countries in the form of increasing direct foreign investment and other forms of investment, e.g., joint ventures, franchising and direct sales of goods and services. At the same time, many African countries, having been independent for about three decades, were taking stock of their social and economic circumstances as well as seeking to build their democratic credentials. They were particularly focused on economic development and wanted to attract foreign investments by putting in place a favourable legal regime. There was also a political and ideological flavour to law reform. By the mid-1990s, the Soviet Union had collapsed and there remained only one viable economic model for development. The multilateral agencies, particularly the IMF and World Bank, promoted a model for development that consisted of several elements: liberalization of the economies by emphasizing the private sector and significantly reducing the role of the state in commerce and finance; open international trade and foreign investment; capacity building whereby overseas consultants who had the requisite skills would partner with local personnel through joint participation in projects; and the realization that commercial laws needed to be supported by wider investments in socio economic infrastructure. ${ }^{21}$ Commercial law reform was undertaken as part of the wider reforms aimed at social, economic and politi-

19 Officially the projects are owned by the host country.

20 That was the era when new international organizations such as UNCITRAL and UNIDROIT got worldwide acceptance for some of their instruments: see J.A.E. Faria, 'Uniform Law and Functional Equivalence: Diverting Paths or Stops Along the Same Road - Thoughts on a New International Regime for Transport Documents', Elon Law Review, Vol. 3, 2011, p. 1, at 3.

21 R. Sarkar, Development Law and International Finance, 2nd edn., Kluwer Law International, London, 2002, p. 38. 
cal development. Those reforms included, for example, the role of women in society, privatization of public enterprises, and education. ${ }^{22}$

The commercial law reform and the prioritization of the laws for reform was done and the "Rule of Law" programme generally, and specifically under "rightsbased commercial law". The fundamental premise was that there was a positive correlation between the rule of law and economic development. ${ }^{23}$ The rule of law emphasized structural legal reform, liberalization of the economy, even-handed administration of justice, the role of civil society, and the avoidance of corruption. ${ }^{24}$ On the side of private law, it focused on the key role of property and contractual rights and their enforcement; while on the public side it focused on public law and constitutional rules for economic development. There were, thus, both procedural and substantive aspects to the conception of rule of law. Procedurally, the rule of law was positivist; it required laws to be public knowledge, clear and to apply equally to everyone. Substantively, laws and rules would be measured against universal standards, for instance justice and fairness. ${ }^{25}$

Under the rule of law programme, Western countries and the international agencies advocated globalization on the one hand, and at the same time insisted on a conducive legal framework for international trade and investment. Structural legal reform, especially for commercial laws, would facilitate globalization without investors having to deal with the complications of different cultures. ${ }^{26}$ There was a ready availability of funds for law reform from international organizations and Western countries, and the funds found ready users to make new laws partly for the sake of economic development and partly to enhance political careers.

\section{Innovations in the Law Reform Process}

Due to the evident lack of local capacity for the extensive commercial law reform project and the desired outcomes, it was envisaged by both the World Bank and the Ministry of Justice in Uganda from the outset that the work would be undertaken by consultants and it was a requirement of the bidding process that overseas consultants paired up with local consultants, the role of the latter being to ensure that the new laws were compatible with the local circumstances. The scale of the work practically meant that there was a bias towards the bigger and wellresourced foreign consulting firms and the tenders for the bigger lots were won by a big consulting US law firm. ${ }^{27}$ The dynamics between the overseas and local

22 Ibid., p. 38 and generally, World Bank, Sub-Saharan Africa: From Crisis to Sustainable Development, World Bank, 1989, chapters 2-3.

23 See e.g. Economic Commission for Africa, African Alternative Framework for Structural Adjustment Programmes, 1989, UN Doc. E/ECA/CM. 15/16 Rev. 3 at p. 17.

24 Sarkar, 2002, p. 28; R.K. Belton, Competing Definitions of the Rule of Law: Implications for Practitioners, Carnegie Papers No. 55 of 2005, available at: <www.CarnegieEndowment.org/pubs> (last accessed 10 August 2017).

25 Sarkar, 2002, p. 29; G.K. Hadfield \& B.R. Weingast, 'Micro-foundations of the Rule of Law', Annual Review of Political Science, Vol. 17, 2014, pp. 21-42.

26 Sarkar, 2002, p. 25.

27 Reid and Priest, in Washington DC (no longer in existence). 
consultants was not always perfect partly due to problems in communication and partly due to the pace of work; nonetheless, the consultants completed the work and produced draft statutes, sometimes with useful commentary, which still had to be presented to, and passed into law by, parliament. While the consultants' reports were submitted to a specialist unit in the Ministry of Justice, progression of the work mainly fell on the Uganda Law Reform Commission, which is mandated to reform and develop laws. It thus fell to the Law Reform Commission, and occasionally to the line ministry, to complete and promote the draft Bills to parliament so that they were passed into law.

It was evident that the law reform commission did not possess adequate human resources and that additional personnel and knowledge were necessary to review and complete all the laws. Consequently, a sequence of practices requiring the co-option of additional technical expertise and community involvement were formalized in the practice of law reform for ensuring that the laws recommended by the law reform commission conform to the socioeconomic circumstances in the country. The formal authority for these practices was section 11 of the Uganda Law Reform Act, which requires public participation in law reform and was understood to mean a significant community engagement in the law reform process in the form of direct interviews and other consultations with those interested or likely to be affected by the law under reform. ${ }^{28}$ Furthermore, the Act also provides for the appointment of lawyers and nonlawyers on the technical side of law reform ${ }^{29}$ and that provision was used to appoint a couple of sociologists who guide the Commission on the public participation component and the use of social science methodology in law reform projects. These practices are in addition to the doctrinal and social-legal research, ${ }^{30}$ in which the law reform staff have acquired considerable expertise, and have been embedded to the extent that the standard law reform methodology is interdisciplinary. ${ }^{31}$

According to the standard law reform methodology just mentioned, the country was divided into four regions (Northern, Eastern, Central and Western Uganda), which can be further subdivided depending on the required sample and degree of penetration of the law reform process. The following steps were taken for the reform of commercial laws (and are taken for other projects) by the law reformers to elicit the views of the selected sample of the public on the laws under reform:

a Identifying and planning the community involvement component of the project. The sociology team and the legal team agreed on the details of the work required for public consultations or interviews. The sociology unit designed the methodology and relevant questionnaire to be used in the process and remained ready to guide the legal team. (Eds.), The Law Reform Promise, Federation Press, Sydney, 2005, p. 160.

29 Section Uganda Law Reform Commission Act section 17.

30 Socio-legal research is multi- or inter-disciplinary: see M. Partington, 'Research', in Opeskin \& Weisbrot, 2005, p. 134 at p. 137.

31 For similar procedures see M. Partington, 'Law Reform: The UK Experience', in M. Tilbury et al. (Eds.), Reforming Law Reform, Hong Kong University Press, Hong Kong, 2014, p. 67, at 78-81. 
b Pre-testing: the questionnaire was piloted using a small population sample in each of the four regions. This required effective coordination with the local political and technical leaders, ${ }^{32}$ who are responsible for identifying the respondents in each of the regions and ensuring that they are available when required. This step also frequently required translating the questions and answers to and from English since, as noted above, a multitude of languages are spoken across the country.

c Public consultations and direct interviews. Most of the public consultations and direct interviews were carried out by the staff of the law reform commission with translators, if necessary, to the selected sample of the population across the four regions of the country. The exercise elicited information and raised public awareness whereby members of the public were consulted on their views on the salient features of the topic under study. Where there was draft legislation or a clear view on the topic under study, the key provisions would be mentioned, discussed and the responses by the public to those provisions would be collated. While the format for public consultations was fairly predictable, some unexpected discourse sometimes did emerge; for instance, the respondents in some of the consultations revealed a sense of being ignored for some of pressing needs to sections of the local community such as copyright for local artistes, contractual relations for the informal sector and the construction industries, and the lack of protection for local seed varieties.

d The Task Force. Early in the project cycle, the Commission constituted a task force of experts on the topic, whose primary role was to contribute their expertise and experience on the topic. ${ }^{33}$ The members of the task force, usually numbering between 15 and 25, commented on the views generated by the in-house research and public consultations, and assisted in shaping and developing the draft legislation. They were intended to be a representative sample of the stakeholders in the proposed legislation; most of them would be lawyers, but they needed not be. They met frequently and consulted the constituencies they represented as the work progressed. Invariably appointees on task forces were: the leading scholar on the topic, the government agency or agencies in charge or directly affected by the law under consideration, a representative from the private sector, a member representing any professional association (for example, the law society), a representative from civil society, a leading lawyer from private practice, a draftsperson, a member of the public representing those likely to be affected by the law, a member representing minority interests on the topic under review, and, of course, the law reform research staff. In usual course, the task force is very important because it reviews the project report, which is frequently the single compre-

32 For instance, each district would have a Commercial Development Officer, who would be involved in all matters relating to commerce.

33 Some projects very early in their formulation include a 'rapid survey' of a few experts (for example, specialist judges and legal practitioners) to assist in the formulation of the issues to be addressed by the project. 
hensive research source on the subject, before it is released for onward transmission.

e Radio Programmes and talk shows. While these have been more commonly utilized for consultations that require very wide participation, for example family law or constitutional matters, they were part of the available arsenal for soliciting views from the public.

f Benchmarking exercises. Particularly for new topics that many lawyers would not be familiar with, such as electronic money, or novel ideas that have potential for wide application in the population, there would be a benchmarking exercise in a neighbouring or overseas country to understand the content and working of the proposed laws. The results of the benchmarking exercise would then feed into the draft legislation. A methodology has been developed for identifying the foreign or overseas experts to consult for benchmarking the laws. In usual practice, the UK is the default destination for benchmarking on commercial law topics, but, ultimately it depends on the subject. On topics such as electronic money, Kenya or Malaysia will do as well if not better than the UK because of fairly similar legal and economic infrastructure. While the benchmarking exercises do not constitute public participation by the local population, they often result in the reformers' better understanding of the practical issues pertaining to the topic, the refinement of research questions, and the addition of details that justify the provisions in the draft bill.

g The project report. A comprehensive report containing the qualitative and quantitative analysis carried out was prepared by the project team including the findings on the current state of the law, a comparative analysis and justifications for provisions in the draft bill. The report was an important reference point for determining whether the extent of the research and public participation in the project was sufficient. ${ }^{34}$

$\mathrm{h}$ Validation workshops. Before the draft bills were finally submitted to the line ministry for progressing them through cabinet and, subsequently, Parliament, there would be a validation exercise with a select, but diverse and large, specialist group to test and validate the ideas in the bill. The salient features of the draft bill would be presented and analysed for logic and potential for practical application. ${ }^{35}$

As can be seen from the above exposition, the process of commercial law reform that began with heavy foreign component in its design and execution ended with an entirely domestic cast. In order to ensure that the laws conform to the contemporary needs of the society, the law reform commission made a concerted

34 On highly controversial topics such as the division of property following divorce the report would also identify what were the majority and minority viewpoints.

35 The debate is rigorous at all the above stages and a subsequent step is not a rubber stamp of the earlier one. On some non-commercial law topics (such as succession, criminal procedure, and marriage and divorce), some new issues emerged at this late stage and the process was referred for more research, consultation or drafting and, in the wider parliamentary process, minority views were sometimes adopted. 
effort at eliciting public participation through the use of a proper sociological methodology. Because the majority of the population was not conversant with the commercial law topics under study, it was evident that the process for public participation would have been more fruitful in legislation that seeks to capture customary, personal or cultural values; for instance, on family and inheritance matters. Nonetheless, it provided an opportunity for the public to articulate their views and assist in shaping commercial law. The process also showed that some communities (in this case the rural communities) were content to follow the lead of the urban dwellers in commercial law matters where commercial law reform was deemed to be more relevant. ${ }^{36}$ Whether the resulting law conforms to contemporary circumstances would, therefore, be judged at the level of the urban dwellers who would be the relevant sample by default.

\section{Evaluation of Major Commercial Law Reform}

The issue whether the major commercial law reform exercise succeeded demands a nuanced answer that looks beyond the corpus of laws that were added to the statute book. The measure of success should include, at least, the initial goal of attaining modern laws that are shaped by the local social and economic circumstances.

The major commercial law reform exercise had become necessary because the statute book was inadequate, outdated and lagging behind the technological developments to spur modern commercial practices. It was positively beneficial, therefore, that Uganda obtained an extensive suite of modern commercial laws. Using metropolitan consultants and local personnel, it made a short-cut to a modern statute book that the country can grow into. The pre-1990s legal system, which was the starting point for reform, had been patterned in form and substance on English law and consisted largely of four sources: domestic legislation, which had been transplanted in toto from English law; (for example, the local equivalent of the English the Companies Acts of 1929 and 1948, the Sale of Goods Act, 1893, and the Bills of Exchange Act, 1882); ${ }^{37}$ the Common Law, for example pertaining to contracts; doctrines of equity; and customary law, provided it was not repugnant to natural justice and morality. ${ }^{38}$ Some of the pre-reform statutes, for example the Bankruptcy Act and the Partnership Act, contained minimal provisions that by reference provided for the application of the English com-

36 This contrasts with, say, the public consultations that preceded the making of the Constitution and those relating to the laws on marriage and divorce, where everyone appeared competent to voice quite a few strong opinions.

37 Colonial legislation provided that those statutes of general application in England that were in force in 1897 would apply in Kenya, those in force in 1902 would apply in Uganda, and those in force in 1920 would apply in Tanganyika. However, the newly independent countries kept importing English legislation beyond those dates. English law was to apply "so far as the local circumstances permit and subject to such qualifications as local circumstances may render necessary." See e.g., S. Owino \& M. Njoroge, Corporations and Partnerships in Kenya, Wolters Kluwer, The Netherlands, 2013, pp. 59-61; D.J. Bakibinga, Company Law in Uganda, Fountain Publishers, Kampala, 2001, p. 1; and in comparative context, K. Zweigert \& H. Kotz, Introduction to Comparative Law, 3rd Revised edition translated by T. Weir, Clarendon, Oxford, 1998, p. 229.

Zweigert \& Kotz, 1998, p. 229. 
mon law, ${ }^{39}$ and there were no statutes on electronic transactions. In contrast, the post-reform statute book boasts of an extensive suite of business, financial, trade and labour laws intended to attract foreign investment and promote trade. ${ }^{40}$ Some statutes, such as the Contracts Act, ${ }^{41}$ are entirely new and codify the modern principles; others are new because they adopt a different approach from those they replaced; ${ }^{42}$ while others significantly expand the scope of pre-existing statutes by codifying the relevant common law and updating the law. ${ }^{43}$

The modern commercial laws in Uganda, many of which are pitched at a higher level of development than is currently useful for much of the population, can be categorized into three for the present analysis:

a Intellectual property laws:

- The Copyright and Neighbouring Rights Act, 2006, Act 19 of 2006;

- The Trade and Services Marks Act, Trade Secrets Protection Act, 2009, Act 2 of 2009;

- The Industrial Properties Act, 2014, Act 3 of 2014;

- The Plant Variety Protection Act, 2014, Act 16 of 2014;

- The Geographical Indications Act, 2013, Act 8 of 2013;

- The Anti-Counterfeiting Goods Bill, 2015, Bill No. 30 of 2015; and

- The National Biotechnology and Biosafety Bill, 2012, Bill No. 18 of 2012.

b E-laws:

- $\quad$ The Electronic Signatures Act, 2011, Act 7 of 2011;

- The Electronic Transactions Act, 2011, Act 8 of 2011; and

- $\quad$ The Computer Misuse Act, 2011, Act 2 of 2011.

c Other commercial laws:

- The Partnership Act, 2010, Act 2 of 2010;

- The Contracts Act, 2010, Act 7 of 2010;

- The Chattels Securities Act, 2014, Act 7 of 2014;

- $\quad$ The Companies Act, 2012, Act 1 of 2012;

- The Insolvency Act, 2011, Act 14 of 2011;

- The Hire Purchase Act, 2009, Act 3 of 2009;

- The Free Zones Act, 2014, Act 5 of 2014;

- The Investment Code Act, Cap. 92 [amended by SI. No 5 of 2011 and Act 6 of 2015];

- The Public Private Partnerships Act, 2015, Act 13 of 2015;

- The Capital Markets Authority Act, Cap. 84 [amended by Act 4 of 2003, Act 12 of 2011 and Act 8 of 2016];

- The Consumer Protection Bill; and

- The Sale of Goods and Supply of Services Bill, 2015, Bill No. 29 of 2015. 
The other EAC partner states similarly enacted corresponding commercial laws in the same period. By way of illustration, Kenya enacted the Insolvency Act, 2015; Moveable Property Security Rights Act, 2017; Companies Act, 2015; Partnerships Act, 2012; Special Economic Zones Act, 2015; Public Private Partnership Act, 2013; Consumer Protection Act, 2012; Kenya Agricultural and Livestock Research Act, 2013; Anti-Counterfeit Act, No. 13 of 2008; Biosafety Act, 2009; Seeds and Plant Varieties (Amendment) Act, 2012; Draft Geographical Indications Bill 2012; while the Kenya Information and Communications Act, Chapter 411A, originally enacted in 1998 was amended in 2009 and 2012 to add Part VIA which provides for electronic transactions. Rwanda, on its part, enacted the Intellectual Property Law, 2009; the Seed and Plant Varieties Law, 2016; Electronic Messages, Electronic Signatures and Electronic Transactions Law, 2010; Companies Law, 2009; and Contracts Law, 2011. The illustrative list from Tanzania includes the Copyright and Neighbouring Rights Act, 1999; Plant Breeders' Rights Act, 2012; Electronic Transactions Act, 2015; and Companies Act, 2002, which came in force in 2006.

As will be evident in this section, this article supports the reforms that took place and argues that the hard part of modernizing a large section of the commercial law statute book was accomplished. Nonetheless, a close look at the titles of the laws shows that the reform focused on the "elite" side of commercial laws for attracting foreign investors and safeguarding their interests, for example intellectual property laws, insolvency and E-laws. Even though the growing local middle class would also benefit from generally applicable commercial laws such as those on contract formation, debtor-creditor relations, secured transactions (the creation and redemption of personal and real security) and remedies, that benefit pales in comparison to the protection of investments. However, most of the local population, steeped in the subsistence agricultural economy, did not deal with issues involving top-end intellectual property laws or E-laws. While they do have interest in intellectual property, their version of intellectual property was not catered for; for example on traditional knowledge and traditional cultural expressions. ${ }^{44}$ What is also visibly missing is the tranche of commercial laws to guide the large informal sector for trade in goods and services, which continues to operate outside the formal legal infrastructure. The drawbacks of a large segment of the economy lying outside official oversight are many; ranging from the loss of tax revenue, time lost in dispute settlement, and the possible human cost for disputes involving substantial amounts of money. ${ }^{45}$ It could be that simplified solutions could be devised to deal with that sector (for example on contract formation, debtor-creditor relations, redemption of security, remedies in construction

44 See e.g., A. Kakooza, The Cultural Divide: Traditional Cultural Expressions and the Entertainment Industry in Developing Economies, JSD thesis at University of Illinois at Urbana-Champaign, Unpublished 2014; but see, in Kenya, the Protection of Traditional Knowledge and Cultural Expressions Act, No. 33 of 2016.

45 For pertinent arguments from the similar region of West Africa, see J. Paquin, Legal Reform and Business Contracts in Developing Economies: Trust, Culture and Law in Dakar, Routledge, London, 2016. 
disputes) business associations, and marketing of agricultural produce - both livestock and food crops, ${ }^{46}$ but that has not happened yet.

Looking beyond the titles, it is noteworthy that the process consisted of legal transposition (also called legal borrowing or legal imitation); which is an acceptable way for the law to develop ${ }^{47}$ and the resulting laws were legal transplants. Specifically, the laws were transplanted from the United States to Uganda and the rest of East Africa. ${ }^{48}$ Among the different theories of transplantation, this was closest to the classic Watsonian sense of transplants because most of the modern commercial laws were developed elsewhere and transplanted to another location where they were not an inevitable outcome of local circumstances. ${ }^{49}$ Similar to Watson's theory on voluntary major transplants, a large portion of the system was moved to a new sphere, in part because there was no comparable legal system, and also, in part, because the people in East Africa voluntarily accepted it. ${ }^{50}$ If the analysis were to stop there, the laws would fail the clear override in law reform statutes, seen above, that the laws should comport with prevailing local social economic circumstances.

On closer scrutiny, however, it ought to be recalled that the consultants did not adopt the overseas laws wholesale; rather, there was real effort to adapt them to the developing country context. For instance, the Chattel Securities Act ${ }^{51}$ adopts the principles of Article 9 of the United States Uniform Commercial Code, but pares them down to a much simpler and shorter statute by removing provisions that will not be required at all in the Ugandan economy. Similarly, the new and reformed Companies Act contains the same principles as the English Companies Act, ${ }^{52}$ but without unnecessary provisions for the local economy. It is fair to argue that, broadly, the reformed laws in Uganda contain the generally applicable principles of international commercial law, or transnational commercial law as it is sometimes called, ${ }^{53}$ and only adopted the framework of United States or UK law. The same principles of transnational commercial law would be found in

46 The analogy is 1940s England, which had simplified contracts for use in informal settings; and also J.W. Katende \& M.R. Chesterman, The Law of Business Associations in East and Central Africa, East African Literature Bureau, 1976 on simplified business documents, where simple precedent forms are provided, but they seem to have been forgotten.

47 Legal transplants have been historically useful across different countries since Roman times: see A. Watson, Legal Transplants: An Approach to Comparative Law, Scottish Academic Press, Edinburgh, 1974.

48 The correct observation is that the template law was developed by a US law firm; that template does not necessarily equal to US law because there was apparent effort to pare it down before transplanting it.

49 Watson, 1974, p. 30. Also G. Mousourakis, 'Legal Transplants and Legal Development: A Jurisprudential and Comparative Law Approach', Acta Juridica Hungarica, 2013, p. 219.

50 This goes against Kahn-Freund who argued that legal transplants cannot succeed outside their political, cultural, social and economic contexts; but they can be politically imposed and nurtured: O. Kahn-Freund, 'Uses and Misuses of Comparative Law', Modern Law Review, Vol. 37, 1974, p. 18 and P. Legrand, 'The Impossibility of Legal Transplants', Maastricht Journal of European and Comparative Law, Vol. 4, 1997, p. 111.

51 Act 7 of 2014.

52 UK Companies Act 2006, Cap 46.

53 Goode et al., 2015. 
model laws and other international harmonization instruments made by bodies such as the UNCITRAL, ${ }^{54}$ which, almost invariably, are abridged or simplified versions of their counterparts in the most advanced countries. Thus, the overseas US or UK laws were at most templates that were modified even before any attempts to export them. One concludes, therefore, that the intention was to transplant the principles and concepts of transnational commercial law and then have local consultants and law reform staff ensure their suitability to the contemporary circumstances of where the laws were transplanted.

It is pertinent to enquire whether the commercial laws were in fact transplanted out of their local context such that they could possibly be legal irritants. ${ }^{55}$ Legal irritants occur when a legal rule that is transferred to a different cultural context does not adapt to the new context, leading to a reconstruction of the rule itself. ${ }^{56}$ There are two possibilities for that to happen; either if the new laws conflict with non-state private law or if they are discordant with state law. On the first score, if it were to be argued that the new commercial laws were legal irritants because of the possible existence of non-state private commercial law that they conflicted with, it would have to be established that there was private regulation of commercial transactions through standardization of business practices as opposed to government regulation. ${ }^{57}$ If such private regulation existed and new laws were transplanted, there could possibly be conflict between the two systems of law and resistance to the new laws. Then it could possibly be argued that there was intrusion of the new laws and substitution of the old regulatory system, or, alternatively, there could be convergence of the private law and the new laws leading to hybridization. The main challenge for such an argument is that standard form contracts are not a source of law and that international commercial practice does not form an autonomous body of law. ${ }^{58}$ Practically, there is little evidence of its application in the commercial law arena in East Africa because the bigger transactions, and indeed most documented transactions, would either follow overseas templates or be based on domestic law. In either event, they would not conflict with the new laws since both would be based on the principles of transnational commercial law, as seen above. On the second point of possible conflict with previously existing state law, previous criticisms of the dynamics of legal transplantation not taking local circumstances into account were dealt with by pairing up overseas and local consultants in the initial drafting of the new

54 E.g., UNCITRAL Model Law on Cross-Border Insolvency (1997) at <www.uncitral.org/uncitral/en/ uncitral_texts/insolvency/1997Model.html> and UNCITRAL Model Law on Electronic Commerce at <www.uncitral.org/uncitral/en/uncitral_texts/electronic_commerce/1996Model.html>.

55 See G. Teubner, 'Legal Irritants: Good Faith in British Law, How Unifying Law Ends Up in New Divergences', in F. Snyder (Ed.), The Europeanisation of Law: The Legal Effects of European Integration, Hart, Oxford, 2000, pp. 243-268.

56 Ibid., pp. 243-268.

57 For a strong view on standard form contracts as law, see J.P. Braithewaite 'Standard Form Contracts as Transnational Law: Evidence from the Derivatives Markets', Modern Law Review, Vol. 75, 2012, pp. 779-805.

58 Rt Hon Lord Justice Mustill, 'The New Lex Mercatoria: The First Twenty-Five Years', in M. Bos \& I. Brownlie (Eds.), Liber Amicorumfor Lord Wilberforce, Oxford University Press, Oxford, 1987, p. 157; Goode et al., 2015, pp. 29-31. 
laws; involving local drafters and other legal experts, and later seeking public participation and broad-based commentary throughout the law-making process leading to the enactment of the laws. The local consultants and legal experts in Uganda were supposed to apply the Janus Law Principle ${ }^{59}$ - consider the history, the future and local circumstances and their work was complemented by task forces and validation exercises. ${ }^{60}$ Furthermore, the national Parliament was sensitive to making laws that were workable and consistent with local circumstances and informed itself through workshops and benchmarking exercises. On this evidence, the new laws were not transposed out of context but, rather, were adapted to suit local circumstances.

That argument still leaves open the question of what exactly were the local "needs" or "contemporary" circumstances as far as commercial law is concerned. That question is answered, ultimately, by parliament when it decides whether or not to pass the draft laws basing, in part, on the report recommending passage of the draft bill. Parliament's hand would be strengthened by a strong and comprehensive report that would have adequately investigated the "needs" and "circumstances" and that in turn draws from the strength of institutional law reform as opposed to ad hoc research or studies more easily influenced by partisan interests. The law reform commission, as an operationally independent government entity, carries out independent research using its in-house expertise and relying on the constructive cooperation and extensive system of support it has with legal and non-legal experts and then compiles a report on the issue. ${ }^{61}$ In the commercial law reform exercise, it became a material factor in determining contemporary circumstances that the large majority of the local population was not operating in the commercial sphere and had very limited international trade or other business practices by global contemporary standards and that, therefore, the relevant sample could not possibly be the wider population. After the initial sampling of the whole country, the research focused on the business community and urban centres; that subset of society that was interested in trade and the wider commercial activities, for the determination of the "contemporary" circumstances and local needs for commercial law.

Still, there were constraints to the role of public consultations in determining the contemporary circumstances since there was no legal vacuum. As noted above, there was a functioning legal system in place consisting of the Common Law legal system, including imperial legislation, and it remained as the foundation for the reforms under discussion. ${ }^{62}$ Arguably, the Common Law itself was evidence of the principles of transnational commercial law of the day and the new laws resulting from the 1995-2015 major commercial law reform exercise were, therefore, an update of earlier transplants. Considering that most of the new laws were more advanced than the current level of development for the majority of the

59 The Janus Law Principle is named after the Roman god Janus, who looks forwards and backwards: Sarkar, 2002, pp. 30-31.

60 See above.

61 Ng'ang'a, 2015, pp. 42-45.

62 H.F. Morris \& J.S. Read, Uganda: The Development of Its Laws and Constitution, Stevens, London, 1966, pp. 318-336; Zweigert \& Kotz, 1998, p. 220. 
population, there was an acceptance by the law reform research staff and Parliament alike that the laws should be forward-looking and that they should provide for a higher level of development than the current position of the country. ${ }^{63}$ Beyond the conventional Watsonian analysis, therefore, the new laws were transplants of necessity intended to steer the country to where the policy makers wanted it to be. ${ }^{64}$ While it could be argued that the process involved an element of imposition because of unequal strength between the overseas and local consultants, the laws were voluntarily adopted as suitable to local circumstances and needs after subjecting them to rigorous debate and scrutiny.

Lastly, it is pertinent to analyse briefly if the commercial law reform project contributed to economic development, which would only be an implied "contemporary circumstance" or "need" of the society for these developing countries since the pursuit of development is not explicitly stated among the law reform objectives. That brief analysis is justified because the involvement of the World Bank was based on the advancement of economic growth. ${ }^{65}$ As a practical matter, the mandate for law reform is limited to recommending laws that provide a conducive environment for development and other government priorities; it being obvious that there are other agencies more directly mandated to steer economic growth and development. On a theoretical level, it is an open question whether the rule of law is the cause or result of economic development. ${ }^{66}$ As seen above, the institutional elements of the rule of law require the existence of laws that are publicly known, the courts, and agencies to enforce the law. ${ }^{67}$ While the World Bank and other multilateral agencies point out that the rule of law enhances economic growth and that there is a direct correlation between the rule of law and high incomes in a country, ${ }^{68}$ there appears to be no direct relationship between changes in legal rules and economic performance. ${ }^{69}$ The better view seems to be that the rule of law is essential to promote sustainable economic growth and development but that it does not operate independently; rather, it positively interacts with other factors such as political stability, trade networks and other domestic and international factors. ${ }^{70}$ In the present context, a good set of commercial laws is one of the contributing factors for the facilitation of economic growth and development. It can, thus, be fairly said that the reform of commercial laws was a positive factor in the facilitation of economic development.

So, this goes against the argument that law and society must be related: see Kahn-Freund, 1974.

64 M. Dean, 'Legal Transplants and Jury Trial in Japan', Legal Studies, Vol. 31, 2011, pp. 570, 590.

65 See above.

66 H. Matsuo, 'The Rule of Law and Economic Development: A Cause or a Result?', in Y. Matsura (Ed.), The Role of Law in Development Past, Present and Future, Nagoya University, Nagoya, 2005, p. 59.

67 Belton, 2005.

68 'The Role of Law' chapter 3 in Governance and The Law: World Development Report 2017; K. Gadio, 'The Role of Law in Development for the African Continent from a Development Agency Perspective', 17 April 2010 (Harvard African Law and Development Conference).

69 Ibid., p. 87.

70 Matsuo, 2005, p. 62; World Development Report 2017, supra note 68, p. 95; see also section C.I above. 
In conclusion, the process of transplanting the new commercial laws addressed contemporary circumstances because the law reform research staff adopted public participation and wide stakeholder engagement at different stages of the process in addition to in-house research. The ultimate result is that a large section of the commercial law statute book has been reformed and contains the principles of modern commercial law while at the same time engendering the confidence of the population. To the extent that any country had a significant influence on the content of the laws, the palpable flavour is that of United States law, for example on chattel securities; followed by English law, for example on company law. Those two countries are frontrunners in the creation of transnational commercial law principles ${ }^{71}$ and it should not be surprising that their law formed the framework principles for EAC commercial law because the legal fundamentals are the same and there is constant interaction among the personnel in the UK and US on the one hand and the EAC on the other. ${ }^{72}$ Ultimately, commercial law reform had an unmistakable positivist and codification result in the form of a clear system of rules effectively in force in a territory. ${ }^{73}$ The ease of access to written modern law puts in place one piece of the jigsaw puzzle towards development - that there should be adequate legal infrastructure. Obviously, law does not plan for or measure the economic success, but it widely accepted that the existence of a conducive legal system facilitates development. ${ }^{74}$ To that extent, commercial law reform took into account contemporary circumstances.

\section{Harmonization of National Commercial Laws in the East African Community}

\section{Background}

This section briefly enquires if the relatively new process of the harmonization of national commercial laws in the EAC achieves its objective of facilitating economic growth or facilitating development, as set out in the EAC treaty, since the benefits of the harmonization of laws, regional integration and globalization are sometimes contested. It then elucidates the different approaches that have been used for the harmonization of laws.

The harmonization of national laws, like the law reform process, is a means of changing the substance of the law. Also, similarly to the law reform process outlined above, the harmonization of national commercial laws sometimes combines the services of overseas consultants and local EAC personnel whereby the initial consultants' ideas are subjected to wider scrutiny. There is a historical backdrop to this modus operandum. Early in the history of the harmonization of national commercial laws in 2010, the EAC commissioned two consultants to

71 Most major trading nations contribute to the formation of transnational commercial law.

72 On constant interaction, see H. Spamann, 'Contemporary Legal Transplants - Legal Families and the Diffusion of (Corporate) Law', Brigham Young University Law Review, 2009.

73 M.D.A. Freeman, Lloyd's Introduction to Jurisprudence, 9th edn., Sweet \& Maxwell, London, 2014. p. 317.

74 See 'Bleak House: The Rule of Law in Africa', The Economist, July 1, 2017, pp. 47-48. 
make concrete proposals for the harmonization of commercial laws that would enhance the commercial sector and advance the EAC's integration. The consultants, a European law firm pairing up with a local law firm in East Africa, ${ }^{75}$ submitted a draft report that was found unsatisfactory when it was subjected to detailed review. ${ }^{76}$ The Sub-committee on the harmonization of laws thereby recommended that subsequent work would be carried out by the Task Force of the Sub-committee on harmonization of laws, and from that early history, the harmonization of laws process is carried out by the Sub-Committee on harmonization of laws, which is comprised of the Chairpersons of the Law Reform Commissions. Much of the preparatory work is carried out by the Task Force of the Subcommittee on the harmonization of laws, and the reporting channels go back in the opposite direction to the Sectoral Council on Legal and Judicial Affairs, then to the Council of Ministers and the Summit. Ultimately, then, much of the harmonization work is done by national law reform commissions; their mandate is not exclusive, though, as this article illustrates. As was noted above, the law reform commissions routinely enquire whether the proposed laws have taken into account the contemporary circumstances. That is because, in addition to inhouse research, the commissions consult widely with relevant experts and interested parties on the topics under scrutiny and validate their findings before transmitting them for the next step in the legislation. This section accordingly adopts the earlier conclusions reached in this article on legal transplantation.

The concept of harmonization of laws is used to refer to the process where laws, regulatory frameworks or standards of states are aligned to make them more uniform and coherent. The method adopted depends on the degree of uniformity desired by the parties undertaking the harmonization process. ${ }^{77}$ In a wider context, harmonization is an important feature of the modern legal regime and has been deployed successfully in European law, jurisdictions with a federal structure and international legal instruments. ${ }^{78}$ Sometimes used interchangeably with "legal approximation", ${ }^{79}$ the two terms are technically different. While "approximation" is the process, broadly understood, of removing undesired or unwarranted differences in national legislation, of bringing different elements closer together by eliminating their difference to accomplish a specific objective, "harmonization", on the other hand, involves a greater degree of integration that replaces national provisions with rules whose provisions are common to all part-

75 Eversheds and African Legal Network, respectively.

76 Press Release: harmonization of commercial laws in progress in the region; East African Community Secretariat, Arusha, Tanzania, February 18, 2010, available at: <www.eac.int>.

77 See P. Craig \& G. de Burca, EU Law Text, Cases and Materials, 6th edn., Oxford University Press, Oxford, 2011, pp. 620-627; P. Jan Slot, 'Harmonisation', European Law Review, Vol. 21, 1996, p. 378.

78 The views critical of harmonization of laws are respectfully acknowledged.

79 See e.g., M. Dougan, 'Approximation of Laws in the EU', in P. Cane \& J. Conaghan (Eds.), The New Oxford Companion of Law, Oxford University Press, Oxford, 2008, p. 42; O. Akseli, 'International Harmonisation of Credit and Security Laws: the Way Forward', in Andenas \& Andersen, 2011, pp. 551, 553-554; E. Lohse, 'The Meaning of Harmonisation in the Context of the European Union - A Process in Need of Definition', in Andenas \& Andersen, ibid., pp. 282, 285. 
ner states. ${ }^{80}$ The harmonization measures include unification, approximation, directives and model laws, as will be seen below.

The general power for the harmonization of laws in the EAC is laid out in article 126(2)(b) of the Treaty, which provides that partner states shall take all necessary steps to harmonize all their national laws appertaining to the Community in order to promote the objectives of the Community. The main objective of the Community is spelt out in the Treaty article 5(1), which is to develop policies and programmes aimed at widening and deepening cooperation among partner states in political, economic, social and cultural fields; research and technology; defence, security and legal and judicial affairs, for their mutual benefit. Furthermore, under article 5(2) of the Treaty, the partner states undertake among themselves to establish a common market. A second source of power for the harmonization of laws is article 14(d) of the Treaty, which gives the Council the power to "make regulations, issue directives, take decisions, make recommendations and give opinions in accordance with the provisions of the Treaty." This is an important power that the Council uses to promote the proper functioning and development of the Community. The third source of power for the harmonization of laws is article 85 (b) and (d) of the Treaty, relating to banking and capital market development, which requires partner states to harmonize banking Acts, and regulatory and legislative frameworks and regulatory structures to create a conducive environment for the movement of capital within the community. These provisions do not create a general power in the Council or the EAC to regulate in the public interest; rather, they only confer a mandate for the adoption of measures that promote EAC integration by removing obstacles to the free movement of goods, services, capital and people. ${ }^{81}$

The main aim of the harmonization of national commercial laws in the EAC is economic advancement. Harmonization is done in furtherance of the EAC objectives to ensure "the attainment of sustainable growth and development of Partner States," and economic development expected to raise the standard of living and improve the quality of life for the population. ${ }^{82}$ Article 5(2) indicates that the end result of the different stages of cooperation is intended to be "accelerated, harmonious and balanced development and sustained expansion of economic activities, the benefit of which shall be equitably shared." While different aspects of development are envisaged, they have, at their core, the improvement in the economic indicators such as increase in the Gross Domestic Product or per capita income. ${ }^{83}$ Practically, the impetus for harmonization of commercial laws is the desire to facilitate economic development in the region ${ }^{84}$ and to improve the investment climate. That is because the harmonization intends to achieve closer London, 2013, pp. 475-479.

81 Accord. Tobacco Advertising Judgment (Germany v Parliament and Council (2000) ECJ.

82 EAC Treaty, Art 5(3).

83 P. Heyne, P.J. Boettke \& D.L. Prychitko, The Economic Way of Thinking, 13th Revised edn., Pearson, Harlow, UK, 2014, pp. 289-320; J. Harvey \& E. Jowsey, Modern Economics, 8th edn., Palgrave Macmillan, Basingtoke, UK, 2007, pp. 343-358. 
economic integration, which eases commercial transactions and offers a larger, more attractive market to the partner states and the world at large. Born of the practical desire to move people, capital, goods and services across national borders, the harmonization of national laws in the EAC positively interacts with the legal instruments created by universal bodies such as the United Nations Commission on International Trade Law (UNCITRAL) and the International Institute for the Unification of Private Law (UNIDROIT), which develop uniform law for worldwide acceptance, and regional integration organizations, in particular the European Union, which are active in the field of legal harmonization. These organizations assume exclusive competence over certain areas of law and have the authority to negotiate international uniform law instruments with states outside their region. ${ }^{85}$ Clearly, then, the harmonization of national laws in the EAC is intended to be at the confluence of regional integration and globalization, both of which are expected to lead to economic development in the EAC region as a whole and in the individual partner states.

Accepting that suitable national laws are conducive to economic development, ${ }^{86}$ it is still debatable whether the harmonization of substantive laws, like the type adopted in the EAC for commercial laws, facilitates trade as is claimed. On the one hand, some scholars argue that the harmonization of laws facilitates trade by, first, bridging gaps or filling vacuums in national commercial laws. Second, harmonization aids the management of legal risk by providing more predictable outcomes for cross-border trade since it reduces the uncertainty inherent in different national legal rules in private international law. Third, the harmonization of national laws also reduces transaction costs in international business because it provides the same rules for both parties who then no longer find it necessary to seek legal advice on the rules of the other party. ${ }^{87}$ On the other hand, it is argued that the harmonization of substantive rules is costly and needless and may in fact hinder international trade; instead, the harmonization efforts should be devoted to contractual choice of law. ${ }^{88}$ While it is acknowledged that even the most successful substantive law harmonization results are not perfect, ${ }^{89}$ and that, ideally, the harmonization of choice of law instruments is also desirable because it enhances party autonomy, on balance the better view is that the harmonization of substantive rules facilitates trade and that will be the perspective adopted in relation to the EAC.

85 See J. Basedow, 'Worldwide Harmonisation of Private Law and Regional Economic Integration General Report', Uniform Law Review, Vol. 8, 2003, pp. 31, 33.

86 See text around notes 67 to 70 , above.

87 E.g., R. Cranston, 'Theorizing Transnational Commercial Law', Texas International Law Journal, Vol. 42, 2007, pp. 597, 601; R. Goode, 'Reflections on the Harmonisation of Commercial Law', Uniform Law Review, Vol. 19, 1991, pp. 54, 72.

88 E.g., P.B. Stephan, 'The Futility of Unification and Harmonisation in International Commercial Law', Virginia Journal of International Law, Vol. 39, 1999, p. 742; J.F. Coyle, 'Rethinking the Commercial Law Treaty', Georgia Law Review, Vol. 45, 2011, p. 343.

89 See e.g., C.P. Gillette \& R.E. Scott, 'The Political Economy of International Sales Law', International Review of Law and Economics, Vol. 25, 2005, pp. 446, 453. 
It is similarly debatable if regionalism based on trade, such as the EAC, enhances economic well-being, which is at the centre of the efforts for the harmonization of laws, as seen above. While critics point to enormous imbalances in access to the benefits of liberalized trade arrangements despite the avowed egalitarian principles, and that developing countries tend to be disadvantaged and disempowered in global trade relations, ${ }^{90}$ scholars also point out substantial benefits in participating in regional bodies within the global economy. First, regionalism contributes to enhancing democratic and economic relations between partner states and other nations; ${ }^{91}$ second, it simplifies trade relations between partner states; and third, it reaps economies of scale by tapping increased foreign investment for a larger market. ${ }^{92}$ While acknowledging that the benefits of regionalism were in the past shared unequally in the EAC, ${ }^{93}$ this article argues that the way forward is to integrate effectively while addressing the constraints and causes for the imbalance in sharing of the increased wealth created by integration. Accordingly, this article endorses both regional integration and the harmonization of commercial laws as contributors to increased wealth and economic development.

\section{Approaches to Harmonization of National Laws in the EAC}

This section details the different approaches that have so far been adopted in the harmonization of EAC commercial laws, focusing on the use of Council directives, which is a new approach in the region. It will be apparent that the harmonization process in the EAC is similar to the processes of the European Union and is intended to produce a harmonious, though not necessarily uniform, legal system. It will also be apparent that the different approaches adopt a consultative approach similar to law reform processes in which there is already embedded the mentality of ensuring that the laws conform to contemporary circumstances. The section confines itself to "active" harmonization that results in the adoption of common rules either from a single regulator or through separate national regulators operating in a coordinated manner within a mutual recognition regime. It does not concern itself with "passive" harmonization, where the overall message in the

90 A. Hippolyte, 'Aspiring for a Constructive TWAIL Approach Towards the International Investment Regime', in S. Schill, C. Tams \& R. Hofmann (Eds.), International Investment Law and Development: Bridging the Gap, 2015 Frankfurt Investment and Economic Law Series; M.N. Jacobs, 'The Offensive Power of Regional Trade Agreements', Journal of World Trade, Vol. 45, No. 4, 2010, p. 767; J. Alvarez, 'Contemporary Foreign Investment Law: “An Empire of Law” or "Law of Empire”?', Alabama Law Review, Vol. 60, 2009, p. 943.

91 J.T. Gathii, 'TWAIL: A Brief History of Its Origins, Its Decentralized Network, and a Tentative Bibliography', Trade, Law and Development, Vol. 3, 2011, p. 26.

92 See generally, J.-C. Maur, 'Regionalism and Trade Facilitation: A Primer', Policy Research Working Paper No. 4464, World Bank, 2008, pp. 6-10; J. Whalley, 'Why Do Countries Seek Regional Trade Agreements?', National Bureau of Economic Research Working Paper 5552, Cambridge, 1996.

93 A point alluded to in the preamble to the EAC Treaty; and generally, E.A. O'Hara \& L.E. Ribstein, The Law Market, Oxford University Press, New York, 2009, p. 34 that powerful contract drafters benefit at the expense of weaker ones. 
harmonized rules affects the general ethos of the population and has an impact beyond the areas that were directly contemplated by the harmonizers. ${ }^{94}$

\section{Approximation of National Laws}

The approximation of laws is provided for under Article 47 of the EAC Common Market Protocol, ${ }^{95}$ where partner states undertake to approximate their national laws and harmonize their policies and systems to implement the common market Protocol. "Approximation" is the process of aligning national legislation with commonly agreed principles of law without necessarily making them uniform. ${ }^{96}$ The aim is to reduce disparities or abolish differences between the laws of member states that might hinder free movement and it is a premise of the approximation process that there is mutual recognition by partner states for the approximated laws of other partner states. ${ }^{97}$ The approximation of laws reduces disparities in the laws, but higher protections may still be possible through national laws. ${ }^{98}$

The key tool for ensuring that the harmonized laws facilitate a development purpose lies in the methodology used by the Sub-committee on the harmonization of laws, which seeks to apply the best international practice to commercial law in the partner states. The sub-committee first studies and analyses various laws of the partner states to establish the gaps, differences, weaknesses and similarities among them and then identifies principles in line with international best practice on the relevant subject and evaluates the existing laws of Partner States against those principles. The evaluation asks two principal questions, ${ }^{99}$ namely, (i) does the national legislation of partner states cover the subject matter; and what is the level of conformity with international best practice and among the EAC partner states. Thereafter, recommendations are made to various partner states to incorporate the missing principles and provisions in their respective laws. There should ideally be three possible outcomes even though reality is different. First, the national legislation may correspond entirely to international best practice, in which case the evaluation is more of a check of conformity. Second, and most commonly, the national may correspond in part to international best practice, in which case the evaluation will identify gaps which may remain and recommend their closure. Third, but rarely, the legislation may appear to conflict with international best practice, in which case the evaluation recommends the modification of the relevant national legislation. Recommendations for

94 On 'active' versus 'passive' harmonization, see Lohse, in Andenas \& Andersen, 2011, pp. 282, 312-313.

95 The Common Markets Protocol was signed on November 20, 2009 and came in force on July 1, 2010.

96 In the EU context, this form of harmonization is also referred to as partial harmonization: see Dougan, in Cane and Conaghan, 2008, p. 42; see also above under III (a).

97 Lohse, 2011, pp. 287 and 311-312, citing, in the European Union, Opinion of AG Stix-Hackl in Case C-436/03 European Parliament v Council [2006] ECR 1-3733, para 59.

98 Accord. Lohse, 2011, p. 311, noting Case-52/00 Commission v French Republic [2002] ECR I-3827, para 17.

99 Similar to Approximation in the when candidate states approximate their laws to the EU laws before joining. See European Commission, Guide to the Approximation of European Union Environmental Legislation. See also Lohse, 2011, p. 291. 
amendment or alignment are then made through the EAC Organs ${ }^{100}$ for adoption in their respective areas of coverage and, as seen above, the process gravitates to international best practice.

The second benefit of the approximation process is the cross-fertilization of ideas among the EAC partner states, which tends to push the general legislative standard higher because the laws are approximated at the highest available standard, which is higher than the lowest common denominator. The third benefit tended to occur at the transposition stage where partner states with inadequate law were spurred to move quicker to implement the approximated laws. Due to limited budgets, competing national interests, and the infancy of the approximation process, the practicality of final stage of the approximation process, which is transposition, ${ }^{101}$ had mixed results in the EAC at the time this research was undertaken. An argument could be made, though, that transposition tended to depend on the expected benefits of the new or amended law rather than legal principle because partner states that had laws that were working reasonably well were slow to implement changes compared to those that desired to change direction significantly or instantly.

\section{EAC Council Directives}

A directive is a legal instrument issued by the Council to achieve harmonization in a given area of cooperation among partner states. The issuance of directives is one of the functions of Council provided for under Article 14(3) (d) of the EAC Treaty and, according to Article 16 of the Treaty, directives are binding on partner states. Furthermore, Article 51 of the EAC Common Market Protocol empowers Council to issue directives as may be necessary for the effective implementation of the Protocol. Under Article 8(2) (b) of the Treaty, partner states are required to confer upon directives of the Community the force of law within its territory and to transpose its provisions in their respective legal frameworks within one year by making regulations or passing an Act of Parliament.

The EAC, in 2014, adopted a comprehensive suite of 27 directives as the chosen approach to the harmonization of the legal and regulatory framework for the capital market laws in the region. That was the first ever use of EAC council directives for the harmonization of laws and it was done to speed up the process of harmonization. ${ }^{102}$ That incident also illustrates the harmonization of national laws by the national Capital Market Authorities, which are specialized regulatory bodies for capital markets, ${ }^{103}$ rather than the law reform commissions. Like law reform commissions, the Capital Market Authorities consulted a wide spectrum of stakeholders on the directives whose content ranges from the familiar procedural requirements, for instance listing and disclosure standards for debt and

100 The Sub-Committee on harmonization reports to the Sectoral Council on Legal and Judicial Affairs but the work is done by the EAC secretariat.

101 Transposition is the implementation stage: it means adapting or changing national laws, rules and procedures so that the harmonized laws are incorporated in the national legal order.

102 Previously, only directives of an administrative nature had been issued.

103 Each one of the EAC partner states (except Burundi and South Sudan) has a capital markets authority. 
equity issuances, to highly specialized topics specifying substantive legal relationships and obligations, for instance in securitizations, collateralized debt obligations, the central securities depositary and collective investment schemes. ${ }^{104}$ The process followed by the EAC before adoption of the directives was also instructive. The initial formulations by consultants were followed by wide consultations, led by the capital market authorities, with the key stakeholders in all the partner states. The debates were vigorous because the partner states had differing levels of development in the capital markets area. In the end, like what we saw in respect of law reform in the first half of this article, the policymakers responsible for the harmonization of national commercial laws chose a higher state of capital markets law for the national legal systems to grow into. ${ }^{105}$ Since the content of the directives is universal and the same lists could as well be replicated in any other jurisdiction, this illustrates the application of transnational commercial law principles in the development and integration of the nascent capital markets in the EAC.

The significant legislative activity and investment in the capital market directives raises the key issue whether the directives facilitate a development purpose. It is noteworthy that the harmonization of capital market laws, and the wider programme on the development of capital markets took place under the EAC Financial Sector Development and Regionalization Project, which is a joint project of the EAC and the World Bank. Furthermore, as noted above, the substantive content of all the capital market directives are inspired by transnational commercial law principles. Finally, many of the directives are pitched at a higher level than the present state of the economy in the majority of the countries. That is because while significant progress has been made in infrastructure and capacity development in the EAC, a litany of challenges remained at the regional and partner states levels, including a narrow investor base, underdeveloped stock exchanges, limited public awareness and investor education, and infrastructure and skills issues. ${ }^{106}$ To illustrate, Rwanda has 6 years' experience of operating debt capital markets, Tanzania has 23 years, Uganda has 21 years' experience, while Kenya had 63 years. There is similarly a large disparity in the number of companies listed on stock exchanges: 62 in Kenya, 21 in Tanzania, 18 in Uganda and 9 in Rwanda. ${ }^{107}$ The policymakers had a choice: they could have either let the capital markets and laws develop nationally and then harmonize the laws, or they

104 Other topics in the first two sets of directives were admission to Trading on a Secondary Exchange, Regional Listings in the Securities Market, Asset-Backed Securities, and Corporate Governance for Securities Market Intermediaries, Anti Money Laundering in the Securities Markets, Investor Compensation Funds, Investor Protection, Takeovers and Mergers, Disaster Recovery and Business Continuity, Conduct of Business, Corporate Governance for Listed Companies, Self-Regulatory Organizations and Securities Exchanges.

105 See section C, supra.

106 See e.g., M. Yabara, 'Capital Market Integration: Progress Ahead of the East African Community Monetary Union', IMF Working Paper, January 2012; P.M. Muthaura, 'Issues and Challenges on Regional Integration of Capital Markets: The East African Experience', IOSCO EMC Conference: Santiago, Chile, 21 November 2012 (unpublished); C. Gatete, 'Promoting EAC Regional Financial Integration', 28 February 2012 (unpublished).

107 Gatete, 2012, p. 8. 
could issue a directive around which national laws would coalesce, and national products, infrastructure and public awareness would grow. The Council chose the latter option. As noted above, commercial laws and the legal system more broadly are intended to be one of the many factors contributing to development. Facilitative laws are expected to work in conjunction with investments in infrastructure and other government and private sector systems to engender development. To the extent that the capital market directives put in place a legal system conducive to development, those directives fulfil a development objective. ${ }^{108}$

\section{Community Acts of the EAC}

A Community Act of the East African Legislative Assembly is designed to unify laws by establishing binding legal obligations at the regional level. Article 8(4) of the Treaty accords precedence to the EAC laws over similar national laws on the same subject matter. ${ }^{109}$ An example of such law is the East African Customs Management Act 2010, which supersedes and takes precedence over all the national laws of the partner states in the management of customs and related matters. However, any provision of law that gives force to the partner state's national laws is supposed to serve a transitional period before the partner state enacts the EAC law in domestic law. As seen above, a particular law may not directly lead to development; rather, the legal system facilitates development working in conjunction with other elements of the economy. Logically, then, a Community Act as a harmonizing measure facilitates development because it puts in place a piece of legislation to work in conjunction with other elements of the private and public sectors to advance the economy.

\section{Model Laws}

The EAC adopted the model law approach to the harmonization of national laws in respect of the law of contracts, where the partner states' laws were outdated and too divergent to be harmonized; and in respect of intellectual property laws, where the partner states did not have the pertinent laws to harmonize. ${ }^{110} \mathrm{~A}$ model law is a legislative text that is recommended to states for enactment as part of their national law. ${ }^{111}$ As such, it is soft law and not binding. It is an appropriate vehicle for modernization and harmonization of national laws when it is expected that states wish to modify the text of the model law to accommodate local requirements and where strict uniformity is not necessary or desirable. ${ }^{112} \mathrm{It}$ is precisely this flexibility that makes a model law potentially easier to negotiate than a text containing obligations that cannot be altered; and that can promote

108 See argument around notes 65-70 above.

109 Similar to the Uniform Acts under OHADA: Martor et al., 2007, p. 3.

110 There were no national laws on the following intellectual property rights enumerated in article 43 of the Protocol: Traditional Knowledge, Genetic Resources, Traditional Cultural Expressions, Geographical Indications, Utility Models, New Plant Varieties, and Layout Designs of Integrated Circuits.

111 E.g., The UNIDROIT Model Law on Leasing 2008; UNCITRAL Model Law on Electronic Commerce 1996.

112 E.g., Sarkar, 2002, p. 76. 
greater acceptance of a model law. Notwithstanding this flexibility, however, states are encouraged to make as few changes as possible when incorporating a model law into their legal systems in order to increase the likelihood of achieving a satisfactory degree of unification and to provide certainty about the extent of unification. A model law is highly effective in fast tracking the harmonization process where written laws do not exist in partner states or require review since it identifies the principles set out in the model law and follows them up with actual statements of law. The national laws based on the model law will not only have a national character but a regional character as well, having emerged from the discussions and principles agreed in the formulation of the model law. A model law also enhances ownership of the harmonized legal instrument since the process leading to the creation of the model law is participatory and benefits from the contribution made by all the EAC Partner States. The effectiveness of a model law depends on whether its provisions materialize into law. Since it emerges from national law reform and legislative bodies, a model law contributes to the legal system, which is one of the required elements for achieving sustainable growth and development. 113

\section{E Conclusion}

The major commercial law reform exercise in the EAC resulted in a suite of modern laws gravitating to Western countries and aligned to the principles of transnational commercial law. That was because the EAC partner states modelled their laws on international best practice. There was also a noticeable march towards codification because there are substantive statutes on topics that were previously predominantly based on the Common Law principles, such as contracts, hire purchase and partnerships and on new areas pertaining to electronic commercial transactions. While the origins and dynamics of the major commercial law reform project point to an element of imposition because of the leadership of the World Bank and metropolitan consultants, there was significant voluntary acceptance of the legal transplants due to the reasons why legal transplants develop; namely, transplants are efficient and command authority, and that in turn attracts investments. As seen above, the mistakes of yesteryear concerning legal transplants were largely avoided by institutional law reform, which builds on specialized inter-disciplinary research and emphasizes public participation and stakeholder involvement to adapt the laws and question any unnecessary intrusion into local circumstances. In the end, the framework documents created by the metropolitan consultants who initially led on the projects were reviewed and adapted because of independent research, public participation, task forces of experts, validation exercises.

This article reached the surprising conclusion that the reformed commercial laws in the EAC reflect the socioeconomic and contemporary circumstances even though large segments of the reformed commercial law statute book were trans- 
planted from other jurisdictions and remain foreign to much of the local population. It was seen that the law reform researchers consciously investigated the issue of what the socioeconomic and contemporary circumstances were; they debated that issue with experts and a wide cross-section of the population; and that the final arbiter on compatibility was the national parliament, which makes the laws. That discourse, both at the level of law reform and legislation, considered the current laws and the present and future needs of society and the resultant commercial laws reflected the contemporary circumstances of the population, especially the needs of the business-oriented community, which is a small, but not insignificant, part of the population. By way of analogy, many laws are deemed compliant with the needs of society generally if they are suitable for the groups that were targeted by the laws. While the laws may be at a higher state of development in some instances, laws must be forward-looking and capable of accommodating both present needs and future developments. Comparing the received commercial law and the reformed commercial law, therefore, both contain the transnational commercial law principles of their day and are justifiable in that respect regardless of how they found their way in the local legislation.

It is a valid criticism that the major commercial law reform project analysed in this article focused on the "elite" side of commercial law and left behind a large and economically significant informal sector. Still, the project was highly beneficial in successfully reforming the laws that were prioritized. It is submitted that the remaining gaps can be filled by local law reformers whose expertise has grown immensely over the last two decades. Simplified solutions could be devised for the informal sector, as was done in the past, ${ }^{114}$ as parts of that sector are motivated to shift to the mainstream economy. It is also a valid observation that the success or otherwise of law reform or the harmonization of laws cannot be determined until the laws are assessed on their practical operation by post-enactment evaluation. ${ }^{115}$ That observation points to matters that impact the efficacy of the laws, which this article did not address. The article confined itself to the development and modernization of EAC commercial laws through law reform and the harmonization of national laws. It did not delve into the issues and challenges that may affect the full flow or attainment of law reform and harmonization, which are considerable in the light of the economic, cultural and political background of the partner states that was outlined above in the introduction. ${ }^{116}$

Concerning the harmonization of national commercial laws in the EAC, we noted that it is driven by the economic imperatives of facilitating the cross-border flow of goods, services, capital and people and generally improving the investment climate in the quest for economic development. We also noted that the harmonization of laws aims to apply the best principles among the six member states or international best practice in commercial law. Because the harmonization pro-

114 See e.g., Katende \& Chesterman, 1976.

115 See Kodo, 2011.

116 An excellent exposition of these factors is Paquin, 2012; Muthaura, 2012; and generally, A. Nahayo, East African Community Tax Harmonisation: A Critical Assessment of Its Viability for Income Tax Laws, Dar es Salaam University Press, Dar es Salaam, 2014. 
cess also considers applicable international instruments, it tends to end up in the application of transnational commercial law. That has two important consequences. First, it has led to a clear move towards codification across all the partner states since partner states are frequently required to adopt further legislation or fill in gaps in existing legislation. Second, harmonization has introduced elements of cross-fertilization, convergence and hybridization in the laws, ${ }^{117}$ not just because the Civil Law tradition interacts with the Common Law tradition in the EAC, but also because transnational commercial law itself is a hybrid system. Still, the different legal traditions and cultures of the EAC partner states are still relevant ${ }^{118}$ because they create a healthy mutual suspicion and healthy debate before common principles are adopted.

Similar to law reform, the harmonization of laws process was consultant-led (but locally controlled), involved external agencies and had outcomes with a distinctly European flavour. That was positively beneficial when harmonizing complex laws such as the capital markets where local expertise was thin and the partner states had widely differing levels of development on a topic. It should be noted that the harmonization of capital market laws was not problematic because the subject matter was a relatively new step for nearly all the partner states and there were no immediately apparent political sensitivities in the substantive law. The situation would arguably be different if there were divergent practices that required alignment or if there were political sensitivities on the subject matter. Nonetheless, the European Union also provides precedents for the different approaches to the harmonization of laws and dealing with political sensitivities, which precedents should be handy in future considering that the EAC is a young region with scanty jurisprudence.

We concluded that the harmonization of national commercial laws facilitates economic development in the EAC even when the capital market laws that we analysed were largely foreign to the general population. That is because, as seen above, good laws and a good legal system are one of the essential building blocks for sustainable economic development even though it is hard to point out the direct contribution made by the laws or legal system. The more specific issue of whether the Council Directives on capital market facilitate a developmental purpose falls under the wider question of whether the harmonization of laws promotes trade and investment. In the EAC context where harmonization of national laws is an aspect of, and contributing to, regional integration, harmonization also touches on another complex issue of whether international and regional trade agreements increase global wealth. These topics are controversial and none of them will attract a unanimous answer except, perhaps, the fact that the benefits of harmonization, transnational commercial law, and regional integration will vary between nations. As seen above, it is the contention of this article that, broadly, the harmonization of national laws increases trade and invest-

117 This is similar to what has happed in OHADA: see Martor et al., 2007, p. 3.

118 For the view that legal families persist after the formal separation of the colonizer and colonized because of the continuous interaction through trade, education and other channels, see Spamann, 2009, p. 1813. 
ment across national borders; that transnational commercial law facilitates the flow of trade; and that international trade agreements and regional integration increase global wealth. We conclude, therefore, that the EAC Council directives and the harmonization of national laws in general facilitate the development objective in the EAC.

We noted that the principles of commercial laws have an international outlook, known as transnational commercial law, which has little regard to geography or culture and makes their wider global acceptance easier. That observation fortifies the conclusions reached on the transplantation of commercial laws in respect of both law reform and harmonization of law exercises in the EAC. It also unintentionally vindicates the received colonial and immediate post-independence commercial laws, which put in place a legal system that was well more advanced than the then general state of development in the EAC. 
M. Zupančič, Judge and Section President, European Court of Human Rights, Strassbourg.

\section{sponsors}

The European Journal of Law Reform is published with financial support from the Swiss Academy of Humanities and Social Sciences and the Stiftung zur Förderung der rechtlichen und wirtschaftlichen Forschung an der Universität Basel. Logistic support is generously provided by the Institute of Advanced Legal Studies at the University of London and by Indiana University Robert H. McKinney School of Law - Indianapolis.

The European Journal of Law Reform is indexed/abstracted in Political Science and Government Abstracts.

\section{aims}

The European Journal of Law Reform is a peer-reviewed journal, and aims to contribute to thinking and debate in its areas of concern by providing a platform for thought-provoking articles of a comparative and progressive nature. The term 'European' in the Journal's title both highlights and draws on Europe's main assets-its intellectual traditions and its diversity. These are reflected in the creative contributions to theory and practice of law from a worldwide authorship representing various schools of thought.

\section{submission of articles}

Manuscripts should be submitted by email to the Managing Editor. A journal style guide is available from the Managing Editor and the Publisher. For more information, please see www.ejlr.org.

\section{publisher}

Eleven International Publishing, Kanonstraat 4-IV, P.O. Box 85576, 2508 CG The Hague, e-mail info@elevenpub.com, website www.elevenpub.com.

\section{subscriptions}

European Journal of Law Reform is published quarterly. Annual subscription rates for 2017 are $€ 255$ (online), $€ 328$ (print and online). Prices exclude VAT and are including postage.

\section{open access policy}

Six months after the publication of the article, the author is free to provide open access to the final pdf of his work. For more information, visit www.elevenjournals. com. Eleven International Publishing assumes that the author agrees to the license which can be found on the website.

Subscription queries and requests for sample copies should be directed to the Publisher. 


\section{european journal \\ of law reform}

\section{volume 192017}

issue 4

Special Issue on Codification
$\Psi$

ROBERT H. MCKINNEY SCHOOL OF LAY

\section{IALS INSTITUTE OF $\mid \begin{aligned} & \text { ADVANCEOOLOF } \\ & \text { ADVANCEDS }\end{aligned}$} LEGAL STUDIES

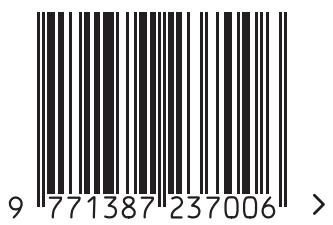

